\title{
Subaltern ecologies in southern Italy
}

\author{
Roberto Sciarelli
}

${ }^{I}$ Centre for Social Studies - Faculty of Economics - University of Coimbra, Coimbra, Portugal.

\begin{abstract}
Italy is a country marked by serious inequalities between its northern and southern regions in terms of welfare, economic production and level of public services. Southern Italy has also suffered serious cases of environmental devastation. A body of literature with a postcolonial approach interprets these inequalities as the outcome of colonial relations of power that have made the south a historic victim of racist representations and authoritarian means of government. Another line of investigation is dedicated to the study of the socio-environmental conflicts which emerged in southern Italy in situations of environmental degradation. The objective of this article is to contribute to build bridges between these two lines of research, identifying the most relevant points of connection and divergence, with the purpose of showing possible paths of common research for a postcolonial political ecology of Southern Italy.
\end{abstract}

Keywords: Southern Italy; political ecology; postcolonial studies

\author{
São Paulo. Vol. 24, 2021 \\ Featured Topic: \\ Decolonial Insurgences and Emancipatory Horizons: \\ Contributions of Political Ecology
}




\section{Introduction}

Ever since the unification of the Italian state, proclaimed on March 17, 1861, there has been great inequality between the northern and the southern regions of the country. This can be seen in the higher poverty levels, lower economic production, worse social services and lower education and employment levels of the southern regions (SVIMEZ, 2018). In addition to these social problems, the Italian south also suffers from serious cases of environmental devastation (PETRILLO, 2009).

In the 1990s a new line of research with a postcolonial approach was developed, and it interpreted those inequalities as elements of a colonial relation of power between the north and the south of Italy. This literature studies the origins and the current elements of southern subalternity in the wider context of Mediterranean colonial history and it detects colonial characteristics in various dispositives of government and representation of southern Italy.

In this area of investigation there are studies of various cases of social conflicts in the 'Mezzogiorno' (as southern Italy is also called), and some of these conflicts occurred in contexts of environmental degradation.

The postcolonial literature on southern Italy is mainly associated with two lines of international research: the first is that of Orientalism (SAID, 1978), committed to the study of the racist representations of Middle Eastern and Mediterranean populations produced along the course of colonialism's history. The second are the Indian postcolonial studies (GUHA; SPIVAK, 2002) which developed the study of the political struggles of subaltern social groups (CHATURVEDI, 2000) and influenced the understanding of social movements in southern Italy (ORIZZONTI MERIDIANI, 2014).

Another, more recent, research field specifically addresses the cases of socioenvironmental conflicts occurring in southern Italy, with contributions stemming from different disciplines, such as environmental history, anthropology and sociology.

In this specific research area there is a widespread recognition of the forms of internal colonialism which characterize the Italian case, but their origins and characteristics are only superficially addressed.

This political ecology literature on the Mezzogiorno is linked to the theoretical field of the 'environmentalism of the poor', which interprets socio-environmental conflicts as ecological distribution conflicts (MARTINEZ-ALIER, 2002). Regarding the relation between Italian internal colonialism and environmental devastation, the fundamental theoretical reference is the concept of environmental racism developed by Robert Bullard (1990).

The objective of this article is to build bridges to connect these areas of investigation, thereby contributing to the development of a political ecology of southern Italy with a postcolonial approach. The text reviews the two lines of literature highlighting their most important elaborations and identifying the new paths of research which could emerge from their theoretical convergence.

The first section of the article presents the main themes addressed by the postco- 
lonial literature on southern Italy. The first paragraph engages with the line of research which examines the construction of the racist and subalternizing discourses produced to describe the region's populations along the course of the modern and contemporary age. The second paragraph presents the analyses conducted about the specific legal provisions used in the Mezzogiorno, such as the special laws and the emergency administration. The third paragraph is dedicated to the postcolonial studies which focus on the social conflicts of ecological matrix in southern Italy.

The second section of the article contains a review of the political ecology studies conducted on southern Italian socio-environmental conflicts. The first paragraph addresses southern Italian industrial history to discuss the question of 'working-class environmentalism'. The second paragraph examines the research conducted on the socioenvironmental conflicts which occurred in the region of Campania during the 'waste crisis' (1994-2012). The third paragraph addresses the literature on socio-environmental conflicts associated with oil extraction in the region of Basilicata.

The article's third section presents a comparative analysis of the connections and divergences between the postcolonial and the political ecology literature on southern Italy. The section aims to show the points of encounter between these two lines of research and indicates possible lines of common research for a postcolonial political ecology of the Mezzogiorno.

\section{Postcolonial and subaltern studies in Southern Italy}

\section{The racializing process}

Italy is a country of the Global North which took part in the historical process of colonialism (LOMBARDI-DIOP; ROMEO, 2012). On the other hand, five centuries of legal, philosophical, socio-anthropological and journalistic literature have represented the southern part of the country in terms of an alterity: an internal south set apart from European civilization (MOE, 2002; SCHNEIDER, 1998).

The reconstruction of this racializing and subalternizing process embraces the discourses produced on southern Italian populations since the beginning of the modern age. This literature shows how the Jesuits who accompanied the conquistadors of the Spanish empire during the $16^{\text {th }}$ and $17^{\text {th }}$ centuries considered the south of Italy as analogous to the territories colonized by European powers. They described the regions of Calabria and Sicily as savage and barbaric territories; as if they were the 'Indies' of Europe, which merely served as training grounds for the missionaries headed towards the Atlantic (CHAVARRIA, 1982). In this way, the south of Italy started to be represented as a liminal space between Christianity and the "other" (MOE, 2002, p. 50-53).

Other studies show that during the colonization of Asia and Africa, when an Orientalist racist view was developed by European powers (SAID, 1978), southern Italy started to be 'Orientalized' in a peculiar way. Lambropoulos (1993) illustrates how travelers from the north appreciated observing the pure, idyllic and 'Hellenistic' territories of Mediterranean Europe. At the same time, they made accusations regarding the 'chaos' 
they found there and considered violence, ignorance and laziness to be the inhabitants' typical characteristics (MOE, 2002).

During the $18^{\text {th }}$ century the common representation of southern Italy was that of "a paradise inhabited by demons" (CROCE, 1927 in MOE, 2002) and the political philosophy of that time participated in this process, using geographic and anthropological stereotypes to explain the absence of liberal institutions in southern Europe (MOE, 2002). Montesquieu (2015, originally published in 1748) in his work De L'esprit des Lois propagated a 'climate theory' to assert that the presence of tyrannical governments in the Mediterranean regions was caused by the servile, irrational, egoistic and violent spirit of the local peoples. In his commentary on Hegel's work 'Elements of the philosophy of right', Eduard Ganz choose the 'lazzaroni', that is, the poor population of Naples (or rather their caricatural representation) as the idealized typification of the dependent, lazy 'plebs', incapable of taking part to civil society (HEGEL, 1987). Being described as wild, superstitious or criminal, the population of Naples - capital of the Kingdom of the Two Sicilies - was imprisoned in depreciative stereotypes (CALARESU, 2007). These representations had consequences and great relevance in the first public debates conducted in Italy after the unification of the country, when the question of the political participation of southern populations in the new State started to be discussed.

Figure 1 - Map comparing the territory of the Kingdom of the

Two Sicilies (1815) with present-day Italian regions

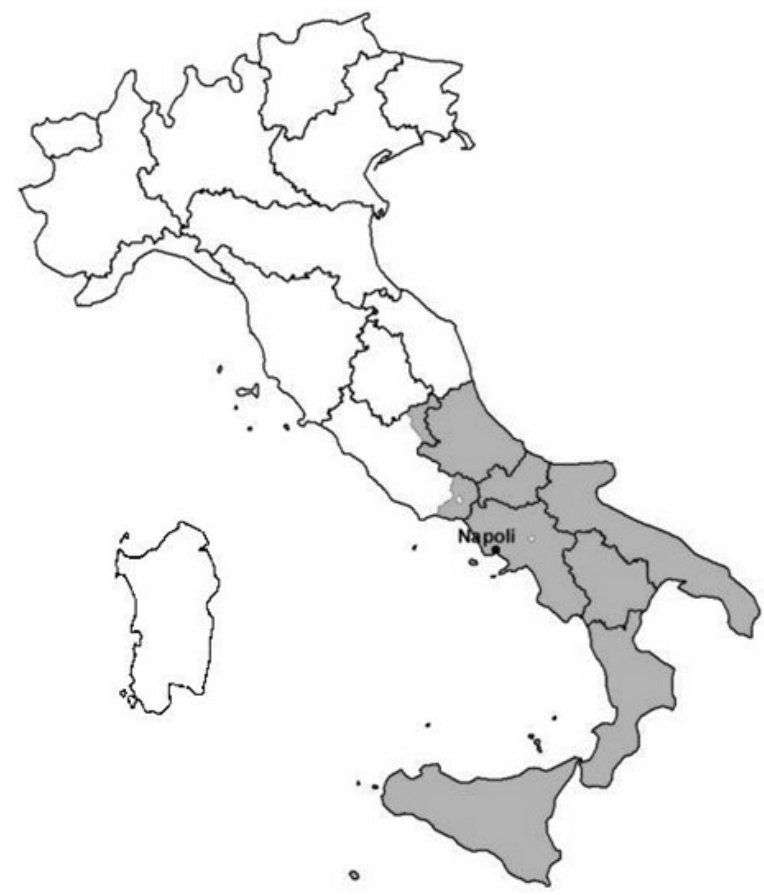

Source: Wikipedia. Available at: https://w.wiki/vCN. 
An analysis of the Italian phenomenon of 'Orientalism in one country' reveals that during the conquest of the Kingdom of the Two Sicilies by the Piedmontese, the Orientalist representation of the south of Italy took on the characteristics that were maintained until today (SCHNEIDER, 1998). Marta Petrusewicz $(1998 ; 2014)$ analyzes the Italian political debate of the years preceding the national unification (1861), showing that it was characterized by a hostile representation of the entire society of the south, described as irretrievably corrupt by centuries of tyranny.

During the phase of unification, the question of southern regions' backwardness acquired increasing importance. With the northern army controlling the south, the social insurgencies which occurred after the country's unification were brutally suppressed and those who participated in them were described in almost monstrous terms, such as barbaric, degenerate, inferior (CAPUSSOTTI; FESTA, 2012).

Petrusewicz (2014) states that the southern bourgeoisie participated in the construction of depreciative discourses on the poor population of their own regions. The bourgeoisie had struggled against the Bourbon monarchy to impose a liberal reform of the state, and in the year 1849 the liberals had experienced a phase of violent political repression (PETRUSEWICZ, 2014). In that critical moment, the monarchy had been supported by the common people of the city of Naples. Therefore, in the eyes of the exiled liberals who contributed to structure the Italian political debate, this fact showed that there was no longer any possibility of autonomous social progress for the southern people and that any social or cultural innovation could only be introduced by external forces (PETRUSEWICZ, 1998, 2014). Petrillo (2014) explains that even today, in Naples, it is common to describe the city as divided in two: a cultured, modern, honest bourgeoisie on one side and a backward, criminal plebeian population on the other.

Festa (2013) analyzes the genealogy of internal racism in Italy and examines the medical-anthropological theories developed after the unification, with references to the anthropological criminology school of Cesare Lombroso. This school postulated theoretical divisions between 'low' and 'high' races within the Italian peninsula, distinguishing the 'Italics' of the south (passionate, individualistic and Mediterranean) from the 'Aryans' of the north (unexcitable, emotionally cold and suited to political life).

Some scholars, observing the longevity of the Orientalist gaze on the Mezzogiorno, coined the term 'Meridionism' (CAZZATO, 2012) in order to study this phenomenon in its specificity. Their main objective is to deconstruct the discursive formation used by modern Europe to frame its identity in opposition to the Mediterranean 'other'. The 'meridian thinking' literature endeavors to subvert the depreciative colonial representations used to describe the south (CASSANO, 2005). Cassano (2011) also confronted the thinking of the poet Giacomo Leopardi (1798-1837) who reflected on the differences between the rationality of the modern, northern populations and the 'imagination' of the ancient and southern populations, apparently more closely connected to nature (LEOPARDI, 2016).

In contrast with this search for supposedly autochthone values of the south, a different kind of literature (CARIELLO; CHAMBERS, 2019) stresses the importance of cultural exchanges among subaltern subjectivities, considering the Italian 'southern 
question' as an element of the general colonial question of the Mediterranean area.

\section{Economic domination, emergency and development}

A line of historical and sociological literature analyzed the legal-political dispositives used for the governance of the Mezzogiorno and showed how, in the hegemonic Italian post-unification discourse, the social and economic disparity which characterized the south motivated interventions which required the attribution of 'special powers' to the national institutions, or even explicitly extra legem actions for the government of the south (PANICO, 2017).

Festa (2014) addresses the first application of a special law in the south, which took place in the years following the unification, the so-called 'Pica Law' (in force from 1863 to 1865). It was designed to facilitate the 'war on brigands', in other words the repression of the southern social insurgencies that arose in the wake of the northern conquest. This law introduced exceptional regulations for territorial governance, including the suspension of the principle of equality before the law, and enabled the installation of military tribunals for the summary judgment of persons involved in acts of rebellion (or merely suspected to do so). Festa explains that the 'war on brigands' caused the destruction of entire towns, economic activities and local cultures, and in this way favored the economic interests of southern Italian ruling classes: the war brutally repressed peasant uprisings and produced an expansion of the large estates owned by southern rural bourgeoisie, which immediately allied with the new monarchy (FESTA, 2014).

Festa (2006) also conducts a detailed analysis of the governance instruments used in Italian history for the urbanistic and economic development of the Mezzogiorno. Studying the continuity of the application of the special laws in southern Italy, the author shows that the legal measures were animated by a 'logic of exceptionality' which marked the history of the great public works projects, the urban transformations and the industrialization of southern Italy. The Italian parliament justified the creation of those special legal frameworks for the south of the country on the basis of Mezzogiorno's economic backwardness. The special laws started to be used at the end of the $19^{\text {th }}$ century and were applied systematically in the years from 1904 to 1908, a period known as the "season of special legislation” for southern Italy (FESTA, 2006).

The first law of this "season" (March 31, 1904) established a series of economic measures for the development of the Basilicata region and provided for the attribution of extraordinary executive powers to a government commissioner. It was followed by other special laws for the city of Naples and the regions of Calabria and Sardinia. Festa highlights the fact that during the phase of special legislation it was common to make use of 'special commissioners', state-nominated officials appointed to deal with emergency situations by concentrating administrative powers and acting in derogation to the ordinary laws (FESTA, 2006). The same author explains that at the center of the hegemonic discourse there was always the need to 'assist' the local institutions of the south, but the result was actually a reduction of those institutions' political autonomy; the special legislation determined the use of administrative bodies and commissioners directly appointed by the 
State, allowing de facto a centralization of political power (FESTA, 2006).

Various special interventions for the economic development of the south were implemented both in the Fascist period and after the second world war (FESTA, 2006). National legislators mostly used industrial and financial capital coming from the north, so that the greater part of the resulting profits came back to northern cities (MARMO, 1978). In an interpretation elaborated by Italian autonomous Marxists, the south's underdevelopment was used as a function of national capitalist accumulation, a resource for the State-managed development (FERRARI BRAVO; SERAFINI, 1972). This interpretation has been recuperated by postcolonial literature: in the book Briganti o emigranti (ORIZZONTI MERIDIANI, 2014) it is considered that the function of the underdevelopment category and the State intervention was to enable the subsumption of southern society to modern capitalism, in an economically and politically subaltern position.

\section{Socio-environmental conflicts in subaltern studies}

According to the theoretical indications of Indian subaltern studies (CHATURVEDI, 2000), the book Briganti o emigranti (Brigands or emigrants) (ORIZZONTI MERIDIANI, 2014) deepens the study of the social conflict expressed by the subaltern territories of the Mezzogiorno. Using a militant co-research methodology, many of the book's essays have been written directly by social movement activists, and four of the essays address conflicts caused by ecological issues. The book describes separate and autonomous mobilizations which are, nevertheless, part of the same process of elaboration of political practices and theoretical tools in the territories of southern Italy (see ORIZZONTI MERIDIANI, 2014).

The first of the four essays addresses the environmental struggles which started in the 1990s in the area of Caserta, a city of the Campania region. (CSOA TEMPO ROSSO, 2014). The text presents the history of various successful grassroots mobilizations which managed to prevent the development of projects with harmful environmental impacts, such as the installation of a refinery, a toxic waste processing plant, new landfills and a gasifier. The authors emphasize the movements' ability to organize themselves as 'new democratic institutions', experimenting forms of direct democracy to organize the struggle while producing knowledge and proposals of environmental policy with the same - or a better - level of elaboration of the ones produced by the State. The article shows how the stakeholders in favor of said installations were animated by antidemocratic attitudes and speculative interests, born from the conjunction between local political powers and criminal organizations.

The essay of the political groups Laboratorio Bancarotta and Cantiere Sociale Quarto Mondo (2014) refers, in the part dedicated to urban ecological issues, to the social movements for the right to the city born in the district of Bagnoli, in Naples. The place suffered from the environmental pollution caused by the steel industry, realized during the 'season of special legislation' for the development of the south. Following the Special Law for the 'economic resurgence' of the city of Naples, the Bagnoli district was occupied by the construction of the Ilva steel plant, which opened in 1910 and became 
part of the State-owned iron and steel company, Italsider, after the second world war. The text criticizes the rhetoric which accused the south of the country of backwardness and underdevelopment, as well as the use of such arguments to legitimize the use of special laws and special commissioners to impose the construction of the noxious installations.

The main ecological and political issue in Bagnoli concerns the decontamination of the area occupied by the steel plant which closed in 1992. The current political conflict emerged between the corporate groups speculating in real estate and the community mobilizations, which started to oppose the concession of public assets and promoted a democratic supervision for the recuperation process. The social movements' practices include the reappropriation of abandoned or degraded spaces, the reactivation of community networks and the organization of grassroot assemblies convened with the purpose of constructing territorial self-governing capacity. The transformation of abandoned spaces into neighborhood's commons is described as an important part of the mobilization (LABORATORIO BANCAROTTA; CANTIERE SOCIALE QUARTO MONDO, 2014).

The third article is dedicated to the theme of oil extraction in southern Italy (PACE; SAVOIA, 2014). This essay begins by criticizing the rhetoric of southern 'backwardness' and the need for 'progress' at the cost of environmental degradation. It presents the extractive economy of southern Italy as a neocolonial economic aggression, proposed in the guise of a great development opportunity. In the authors' vision, capitalism in the Mezzogiorno keeps producing new 'enclosures' and is marked by 'conquering' modalities which have been maintained since the northern conquest of southern Italy.

The essay highlights the fact that the history of the oil industry began in 1861, year of the unification, and that the Italian tax and royalties system is extremely favorable for the multinational corporations. The main site of crude oil extraction is Val d'Agri, in the Basilicata region, and it provides an "excellent example of neocolonial capitalism's mythopoeia" (PACE; SAVOIA, 2014). Here the benefits for corporations like ENI, Shell, Total coexist with local economic impoverishment. The authors emphasize that the pollution caused by the oil industry leads to a high incidence of respiratory and oncological diseases in the population of the territory, while also hampering the development of more traditional economic activities based on agriculture and connected to the protection of natural ecosystems.

Festa (2014), cited above, describes the environmental crisis associated to waste disposal in the region of Campania, a crisis which motivated the application of a state of emergency which lasted from 1994 to 2012. His article analyzes the evolution of racist discourse against the southern population in a context in which the groups of activists and inhabitants who contested the antidemocratic choice of nominating a special commissioner to manage the environmental crisis were almost considered as enemies of the state. According to the author, state institutions and mainstream media described the social movements as composed of 'ignorant', 'selfish', and 'primitive' people, since they were opposing the modernity represented by landfills and incinerators. The mobilizations, on the other hand, managed to valorize their own forms of self-organization, fostering a community spirit in the polluted territories and organizing grassroots assemblies to produce 
alternative analyses and policy proposals for the solution of the crisis.

The studies quoted above attribute great importance to "self-organization as a tradition of the southern public spirit" (PIPERNO, 1997, in FESTA, 2014). Different authors have stressed the ability of southern Italian social movements to produce their own autonomous forms of democratic and community organization as an alternative to the parties, unions and other organizations involved in the national representative democracy process (FESTA, 2003). The analysis of these conflicts in relation to the history of Orientalist representations and colonial governance of southern Italy shows that socio-environmental mobilizations may be an important way for subaltern populations to express their own voice (CARUSO, 2014).

Another book, Il silenzio della polvere (PETRILLO, 2015), also uses co-research methodologies and postcolonial approach to study a case of social conflict in southern Italy. The book reports on the cases of workers poisoned by asbestos treatment processes in the Campania region. Since the 1980s, hundreds of railway wagons were sent to the city of Avellino so that the new iso-chemical installations could remove asbestos paneling. Petrillo (2015) links those deadly activities to the Italian context of internal colonialism, in which the southern workers' lives were considered as disposable and exploitable without any form of health protection.

\section{Political ecology in the Italian south}

Figure 2 - Map of present-day Italian regions

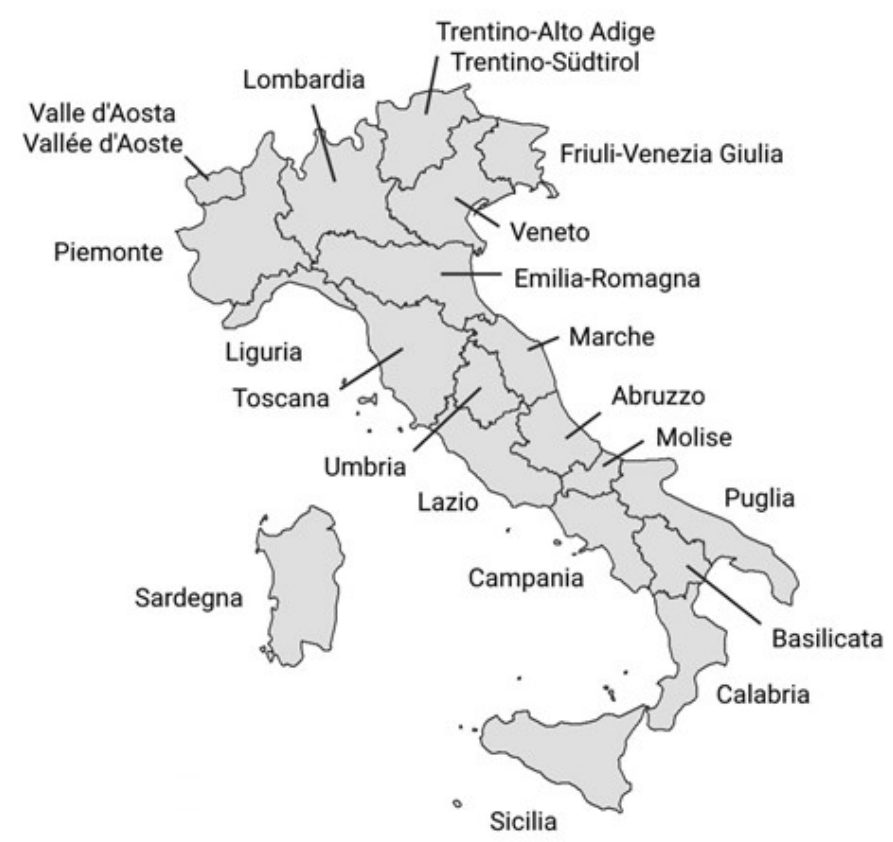

Source: Wikipedia. Available at: https://w.wiki/vCQ. 


\section{The industrialization process and its conflicts}

There is a robust line of literature on the socio-environmental conflicts of southern Italy which addresses the sphere of power relations in the context of industrial production. An author with considerable production on this issue, Stefania Barca, has also conducted research on the origins of southern Italian industrialization. Her book 'Enclosing Water' (BARCA, 2010) refers to the industrialization process in the Kingdom of the Two Sicilies in the $18^{\text {th }}$ and $19^{\text {th }}$ centuries, describing the history of the 'enclosures and improvement project', inspired by the elaborations of the Neapolitan school of political economy, which viewed the State as the entity responsible for making nature economically productive.

Her study reveals how a colonial gaze towards the territories of the south originated within the circles of the local intellectuals, also due to their encounter with the European culture of the Enlightenment and with modern political economy. The cultural elites of the Bourbon kingdom were the first to describe southern society as 'backward', and they did so with the intention of liberating natural resources from the bonds of feudal and customary rights while establishing, instead, individual property rights (BARCA, 2010). The author points out that it was only Joseph Bonaparte, chosen by the French as King of Naples, who actually managed to abolish the feudal regime in southern Italy in 1806. This fact shows that the liberal legal system which then favored industrial development actually arrived in the south of Italy in the hybrid form of a colonial state, which brandished the flags of 'progress' and 'rationality' (BARCA, 2010).

In her references to the history of the Italian workers' mobilizations over health issues, Barca (2014) explains that the workers and their families paid most dearly for the environmental changes that accompanied the decades of intense industrialization after the second world war. This fact also contributed to the emergence of an environmental awareness on the part of the workers. The studies on 'working-class environmentalism' in southern Italy refer to the case of the city of Taranto, in the Apulia region, home to Europe's biggest steel plant. This industrial establishment, privatized in 1995, was once part of Italsider; the same state-owned corporation which ran the steel plant of the Bagnoli district of Naples (BARCA; LEONARDI, 2016).

Leonardi (2013) analyzes the Taranto case from the perspective of working-class environmentalism and constructs a critique of the apparently inevitable contradiction between health and work. Regarding the health consequences for the city's inhabitants stemming from the steel production, this literature highlights the fact that, compared to the Italian average, Taranto has higher infant mortality rates and a higher incidence of cancer and other lethal diseases, all attributable to the pollution caused by steel production (see BARCA; LEONARDI, 2016). Furthermore, these authors show that the local population has been subjected to a form of 'occupational blackmail', being forced to remain in a condition of environmental injustice because if the steel plant were to disappear, so would their only source of income (LEONARDI, 2013; BARCA; LEONARDI, 2018).

Leonardi's (2013) objective is to discuss the possibility of other patterns of relation between environment, work and health, recognizing the power of the inhabitants/workers to decide "what", "how" and "where" to produce. This intention is shared by the ecolo- 
gist movement of the city, which criticizes the industrialist choices of the institutions, claiming greater territorial democracy (LEONARDI, 2013).

Stefania Barca (2014) continues to investigate the conflict between environment and work in Taranto, considering it as a political dichotomy that can be overcome. She argues that the case of Taranto could show the path towards a socially fair ecological transition conducted directly by the workers' communities. Her article shows that the working-class communities have been the protagonists of the ecological movement and that a greater autonomy for them could be a source of sustainable economic and environmental policies.

More recent articles (BARCA; LEONARDI, 2016, 2018) focus on the evolution of Taranto's workers and environmental movement. They analyze how the movement shaped itself into a form of 'community unionism' in order to renegotiate the terms of compatibility between industrial production and socio-environmental wellbeing. Such organization managed to innovate the forms of political participation and made the local working-class people perceive environmentalism as their legitimate right, thereby breaking down the cognitive frontiers fixed by the industrialist imperative.

Barca and Leonardi (2018) interpret the socio-environmental conflict in Taranto as a way to oppose colonial forms of division of labor. Their article considers the situation of environmental injustice in Taranto as an effect of the subordination of the spheres of reproduction and territorial ecology to the imperative of production. The origin of this colonial division of labor is associated to the Italian internal colonization process, profoundly based on racist representations of the inhabitants of the south, considered to be in need of modernization (BARCA; LEONARDI, 2018). The development of heavy industry in the south was necessary to improve the competitiveness of northern industries. Taranto was thus transformed into a 'sacrifice zone', entirely dedicated to the 'industrial monoculture' of steel (BARCA; LEONARDI, 2018).

The same article connects the sexual division of labor in Taranto with the development of community unionism, which evolved in relation to the contradiction between economic production and social reproduction. The sphere of social reproduction has been completely invisibilized, especially because of the division of labor between men, factory workers, and women, domestic workers. That situation changed in the 2000s, when the question of health started to connect the struggles of the workers with the mobilization against environmental injustice. In this phase the women of Taranto have become vigorous political protagonists and played a central role in community organizing (BARCA; LEONARDI, 2018).

\section{The waste crisis and environmental emergency in the region of Campania}

The expression 'waste crisis' of the Campania region refers to the state of emergency issued by national authorities to address serious environmental problems related to waste collection and disposal in the provinces of Naples and Caserta, in the years from 1994 to 2012. This long environmental crisis has been thoroughly analyzed by authors with a postcolonial theoretical approach (PETRILLO, 2015; CSOA TEMPO ROSSO, 2014; 
FESTA, 2014). For this reason, and in the light of this article's objectives, it is important to analyze the considerable body of literature of political ecology which addresses the same issue. Generally speaking, this literature acknowledges that the environmental crisis was caused by the alliance between political, economic and criminal powers which organized the illegal transfer of northern Italian and European industrial waste towards Campania since the 1980s. Consequently, these studies also acknowledge the political legitimacy of the environmental conflicts generated by the social opposition to the many harmful projects that the authorities were proposing as solutions to the crisis, such as the installation of new landfills and incinerators (PETRILLO, 2009; ARMIERO, 2014).

The issue of "environmental emergency" is a central theme in this literature. Armiero and D'Alisa (2012) describe the articulation of the environmental struggles in the authoritarian political context produced by the state of emergency, which was accompanied by the designation of various special commissioners endowed with the special power to impose solutions that violated regional, national and European laws. The authors criticize the management of the crisis realized within the state of emergency, because it enabled the repression of the mobilizations for environmental justice and hindered the development of political alternatives to technocratic solutions. This proved to be harmful to the population of the territory, which were also described as uncivilized and ignorant by mainstream political discourse (ARMIERO; D'ALISA, 2012). D'Alisa et al. (2010) report that the central government even decided to deploy the army in the territories selected for the construction of incinerators against the will of the local population. Moreover, with a decree issued by the Italian government in 2008, the participation in political protests close to the areas of the landfills became a penal felony (D'ALISA et al., 2010).

In their analyses of these authoritarian policies, various authors have stressed the importance of the alliance formed between the eco-mafias and that part of the business world interested in economizing money in the waste disposal process. The authors consider that the absence of adequate grassroots surveillance produced by the state of emergency favored the criminal firms which had strong links with the political elite (IACUELLI, 2007; D'ALISA et al., 2010).

Caggiano and De Rosa (2015) show the value of autonomous social cooperation in combating the environmental degradation caused by the waste crisis. The new social cooperatives and the activists involved in the ecological movement propose a vision of the relationship between society and nature capable of surpassing the logic of exploitation, acknowledging the interdependence of nature and society (CAGGIANO; DE ROSA, 2015). Discussing the same matter, Armiero (2008) notes that through their participation in the socio-environmental conflicts, the inhabitants of the area of Naples have acquired a new vision of the frontier between artificial and natural, increasingly connecting themselves with the natural processes of their land. The environmental crisis connected urban and rural movements, revealing the relations between the domain of nature and the domain of the human beings that inhabit it.

These themes are addressed in greater depth through projects of 'guerilla narratives' (ARMIERO et al., 2019) that set out to explore the 'toxic autobiographies' of the groups 
of people which live in situations of environmental degradation. Iengo and Armiero (2017) argue that "environmental crises are also crises of knowledge and science". Regarding the environmental conflicts in the Campania region, they assert that the State's strategy was to make the injustice of the contamination caused by landfills and toxic waste invisible, attributing responsibility for the diffusion of sickness to the habits of the inhabitants and denying any responsibility on the part of the companies or the institutions.

Armiero and De Rosa (2017) show that the environmental movements expressed a strategy of politicization of the bodily experience of disease with the aim of breaking down the frontiers between emotional and scientific discourse. Their article shows that the environmental movements in Campania are moving away from a purely rational conception of political action: the sensuous experience of pollution corresponds to a bodily etiology of political subjectivation and resistance (ARMIERO; DE ROSA, 2017).

Lastly, Armiero (2014) delves deeper on the issue of environmental conflicts' narratives and analyzes the formation of knowledges which emerge from political participation in territorial struggles. The article compares the descriptions of the figure of the 'savage', as reconstructed by the Latin-American decolonial literature (SANTOS, 2007), and the racializing rhetoric developed against the populations of the Campania region involved in the struggles. The author criticizes the discursive paradigm of the 'savage' and its application in relation to socio-environmental conflicts (used by the authorities to justify political repression), especially because that paradigm conceals the complexity of the relationship between territorial movements and science. The activists managed to overcome the dichotomy between scientific knowledge, often used as a governance tool, and local knowledge, understood as an instrument of autonomy and struggle. They did so by exploring the plurality of scientific knowledges and using experts' opinions strategically, to support the claims of the mobilization (ARMIERO, 2014).

Most of the authors which contributed to this line of research propose to construct new theory alongside the knowledges already elaborated by the contaminated populations (ARMIERO et al., 2019). In his study on the biopolitics of the environmental emergency, Petrillo (2009) declares his preference for the voices of the men and women who were the protagonists of the struggles against the landfills, as well as his distance from the discourses of the institutions. The objective of the mentioned Toxic Biographies project is precisely to sabotage the 'toxic narratives' that naturalize the environmental devastation produced by capitalism and to valorize the narratives which stemmed from the mobilized territories.

\section{Extractive industry and conflicts between forms of knowledge}

Interesting contributions to the study of socio-environmental conflicts in the Italian south have come from the field of anthropology, which produced relevant research associated with the extraction of crude oil in the Basilicata region. The socio-environmental conflicts in the south are presented in the form of conflicts around the legitimacy of scientific knowledge. Research conducted in the Val D'Agri area shows the dialectic between the different forms of rationality which are present in the contaminated zones, in the context of economically vulnerable territories also affected by oil extraction (AL- 
LIEGRO, 2012).

One of the conclusions of these studies is that in order to control the territory of Basilicata and use it as a basin of oil extraction, the multinational corporations had to activate a strategy of symbolic domination of the collective imaginary (ALLIEGRO, 2012). The extractive industry had to present itself as the solution to Basilicata's chronic problems of backwardness, poverty and underdevelopment, capable of transforming it into a rich, prosperous and developed region.

Alliegro presents oil extraction as the result of strongly unequal power relations among economic subjects and local communities (ALLIEGRO, 2012). He also explains the origins of the social movement which questioned the extractivist rhetoric. The movement gained strength thanks to its ability to contest the forms of technical and scientific knowledge which supported the oil companies, to which it opposed the subjective knowledge of the body, that is, the possibility to recognize territorial pollution through physical sensation, instead of making recourse to the State's and corporations' technical personnel, which denied the environmental degradation. Noticing a weak point of the protest, the author shows that the environmental movement did not manage to transform the local communities into a completely united front (ALLIEGRO, 2016).

In other studies, Alliegro shows how the extractive industry legitimizes itself by imposing a highly scientific discourse, delegitimizing the opposition by producing a political debate dominated by the 'science of the State' and the 'science of the company'. This high degree of certification of reality is partially contrasted with the 'proximity science' generated by the encounter between scientists and local communities. On the one hand, this encounter provides a fruitful cultural mediation by spreading scientific and legal knowledge. On the other hand, the eruption of positivist languages and approaches generates a "distancing from the endogenous systems which register discomfort" (ALLIEGRO, 2016), that is, from the forms of knowledge that emerge directly from sensory experience, delegitimizing in this way the autonomous assessments regarding the state of human and environmental health. 
Figure 3 - Map of the provinces of the south of Italy showing the areas of the socio-environmental conflicts addressed in this article

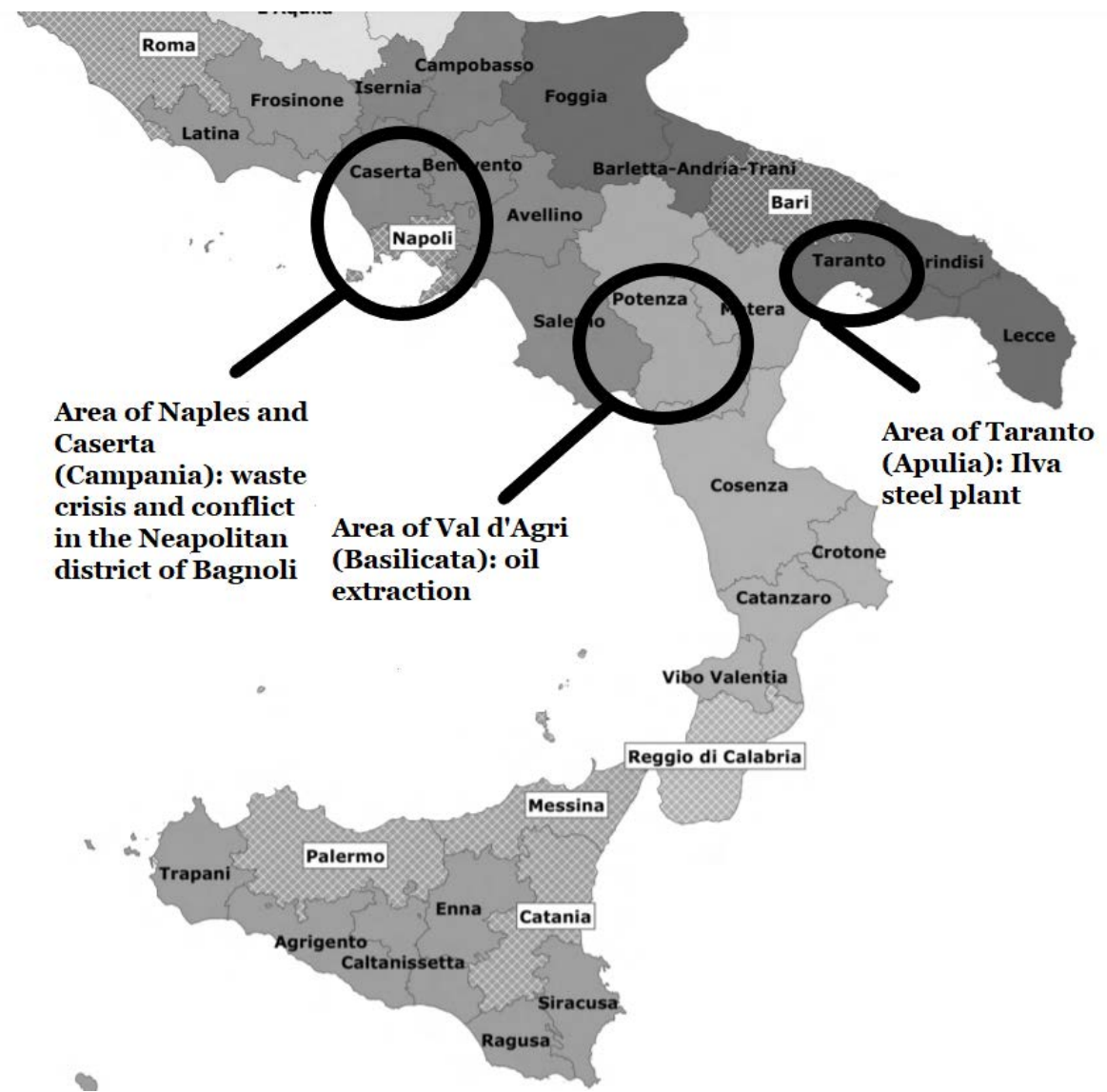

Source of the original image: Unione Province d'Italia - UPI. Available at: https://bit.ly/3a6K4Xu.

\section{Resonances, missed opportunities and possible paths of research}

The combined reading of the postcolonial and the political ecology literature focused on southern Italy reveals a notable convergence of the two bodies of research, regarding both the addressed issues and the conclusions drawn. This is particularly evident in the postcolonial literature dedicated to socio-environmental conflicts (CSOA TEMPO ROSSO, 2014; FESTA, 2014; LABORATORIO BANCAROTTA; CANTIERE SOCIALE QUARTO MONDO, 2014; PACE; SAVOIA, 2014; PETRILLO, 2015). Apart from the similarities, however, there are also a few important points of divergence; perhaps all the more important because they point at the possibilities of criticism, encounter and discussion between the two lines of investigation within future paths of research.

Excellent examples of the conjunction of these two literatures can be found in the studies characterized by a historical approach, such as Enclosing Water (BARCA, 2010) 
or Il silenzio della polvere (PETRILLO, 2015). In the former, Barca addresses the issue of the subalternizing representations produced within southern Italy basing her research on the works of Moe (2002) and Petrusewicz (1998), which have great relevance in postcolonial literature. Petrillo, for his part, studied both the history of industrialization and the socio-environmental conflicts related to waste management in the region of Campania (PETRILLO, 2009), highlighting the phenomenon of Italian internal colonialism and stimulating dialogue between postcolonial studies and political ecology. Examples like these show that, in some cases, the two literatures are already coming together, and that this process can produce relevant theoretical innovations.

The critique of racist discourse against southern Italy is central to the postcolonial studies and the existence of a subalternizing discourse is addressed by political ecology too. The two lines of research stress the evolution of such discourses against territorial activists (above all ARMIERO, 2014, and FESTA, 2014). With the exception of Barca and Leonardi (2018), Caggiano and De Rosa (2015), Barca (2010) and Petrillo (2009), a considerable part of the political ecology literature (ARMIERO; DE ROSA, 2017; IENGO; ARMIERO, 2017; BARCA; LEONARDI, 2016) does not make any explicit reference to the postcolonial literature on the Mezzogiorno. Armiero (2014) analyzes the figure of the 'savage' referring to Latin-American decolonial literature (SANTOS, 2007) but that elaboration is not accompanied by any comparison with the depreciative descriptions of the old 'brigands' of southern Italy. In the same way, Demaria and D'Alisa (2013) refer to the 'subaltern peoples' of southern Italy, but they do not explore the colonial roots of that subaltern condition. Political ecology in general acknowledges the phenomenon of Italian internal colonialism but it does not seriously engage with the theoretical reflections (FESTA, 2013; MOE, 2002; SCHNEIDER, 1998; PETRUSEWICZ, 1998) already developed on the issue.

Both literatures attribute great importance to the issue of the legal instruments connected to the state of emergency, considered to be a very centralizing governance tool enforced to the detriment of local democracy. The postcolonial literature on southern Italy makes a more precise analysis of the historical origins of these legal provisions (FESTA, 2006), while the political ecology literature observes their contemporary application in situations of environmental devastation and conflict (PIPERNO, 2009; D'ALISA ET AL., 2010; ARMIERO; D'ALISA, 2012). Therefore, the two lines of research complete each other's analyses and arrive independently at similar conclusions, even though they do not actually make explicit references to one another. An exception to this lack of references can be found in the article of Caggiano and De Rosa (2015) which addresses the relations between the emergency provisions and the racialization of the southern Italian population using a reflection found in Festa (2014), which analyzes the historical origins of those phenomena using a postcolonial approach.

An important element of the two literatures is the critique of the concept of development. The issue of the imposition of economic development is central to the postcolonial literature which analyzes it from the first phases of special legislation (FESTA, 2006) until the more recent extractive activities (PACE; SAVOIA, 2014). On the basis of his 
studies on the environmental conflicts in the Basilicata region, Alliegro (2012; 2016) addresses the issue of oil extraction to criticize the dichotomy between modernity and archaism. The different authors agree about the fact that the oil companies reinforced their position in the region by exercising their power on the collective imaginary of the local population. One important point of divergence is in the positioning from which the analyses are developed: the authors of Orizzonti Meridiani participate directly in the environmental struggles that they narrate. This positioning difference is accompanied by partial divergencies in the conclusions reached: Alliegro $(2012 ; 2016)$ stresses more than Pace and Savoia (2014) the weak points of the environmental mobilization and the absence of any unified front against oil extraction. Despite the proximity of the themes they address, these authors seem to ignore each other's works and thereby lose an opportunity to connect points of view elaborated in different ways.

On the other hand, the resolution to produce knowledge together with the territorial struggles is very much present in both bodies of literature (PETRILLO, 2009; ARMIERO, 2014; ORIZZONTI MERIDIANI, 2014; ARMIERO et al., 2019). The texts of Briganti o emigranti (ORIZZONTI MERIDIANI, 2014) propose the question of overcoming colonial thinking through the knowledges produced by subaltern struggles. The literature of political ecology also considers the sensory perceptions of the local populations as a source of knowledge (ARMIERO; DE ROSA, 2017; IENGO; ARMIERO, 2017; ALLIEGRO; 2012, 2016). Comparing the methodologies of co-research developed by political ecology and postcolonial studies could prove to be particularly important to improve the understanding of the different forms of subaltern social conflict in southern Italy.

Through the studies produced on the case of Taranto (BARCA; LEONARDI, 2016, 2018) political ecology literature has explored the characteristics of the ecologist struggles which emerged in contexts dominated by industrial production, putting "working-class environmentalism" in relation to the colonial division of labor which occurs in Italy. Similar studies have been conducted by Petrillo (2015) which, like Barca and Leonardi, explains the phenomenon of industrial pollution in the light of the history of internal colonialism in southern Italy. The theory of working-class environmentalism has relevant analogies with the subaltern studies which compose Briganti o emigranti, especially for the relevance given to the issues of the distribution of political power in the hands of the inhabitants/workers and of the construction of political autonomy in opposition to production imperatives. Therefore, the two bodies of literature could evolve together while studying the democratic claims emerged in the socio-environmental conflicts of the Mezzogiorno in greater depth.

Finally, analyzing the etiology of working-class environmentalism, the line of research of political ecology problematizes gender issues, interpreting the contradiction between work and health as a dialectic between production and reproduction (BARCA; LEONARDI, 2018). This theoretical advancement is particularly relevant. In the case of a greater approximation between political ecology and postcolonial studies, the intersections between southern Italian subalternity, class and gender relations could be more precisely understood. 


\section{Conclusions}

This text has reviewed the main lines of research of postcolonial studies and political ecology which focus on southern Italy. The most important aspects of the two literatures have been analyzed and compared, in the endeavor to show their main points of connection and divergence and to indicate possible paths of common research.

The two literatures present considerable convergences: they address similar issues, reach comparable conclusions, propose similar criticisms of the government dispositives, discourses and practices applied in southern territories, share a stance of proximity and support to the social struggles and similar co-research methodologies.

However, these bodies of literature have evolved independently and have only superficially dialogued with one another. The result is that the postcolonial literature does not fully recognize the ecological relevance of its historical and sociological studies, while the political ecology literature contains very few references to the specific history of colonial discourses and practices applied in southern Italy, even if it acknowledges its existence and importance.

Despite these critical aspects, it is quite clear that the points of connection far outnumber those of divergence. The recognition of their proximity and a greater communication between the two lines of research could result in precious theoretical evolutions, giving life to a more complete field of research of postcolonial political ecology to address southern Italian specific situation. This possible path of investigation could embrace far-reaching questions, such as the historical roots of the region's economic and environmental policies or more precise analyses of the class, gender, race and power relations brought to light by the socio-environmental conflicts.

\section{Acknowledgements}

The realization of this article has been possible thanks to the doctoral scholarship granted to the author by the Portuguese Foundation for Science and Technology (Fundação para a Ciência e Tecnologia - FCT). 


\section{References}

ALLIEGRO, E. V. Il totem nero: petrolio, sviluppo e conflitti in Basilicata. Antropologia politica di una provincia italiana. Roma: Cisu, 2012.

ALLIEGRO, E. V. Crisi ecologica e processi di "identizzazione": l'esempio delle estrazioni petrolifere in Basilicata. EtnoAntropologia, Matera, v. 4, n. 2, p. 5-32, 2016.

ARMIERO, M. Seeing like a protester: nature, power, and environmental struggles. Left History, Toronto, v. 13, n. 1, p. 59-76, 2008.

ARMIERO, M. Is there an indigenous knowledge in the Global North? Re/inventing local knowledge and communities in the struggles over garbage and incinerators in Campania. Italy. Estudos de Sociologia, v. 1, n. 20, maio 2014. ISSN 2317-5427. Available at: < <ttps://periodicos.ufpe.br/revistas/revsocio/article/view/235511/28498>. Accessed on: December 7, 2020.

ARMIERO, M. et al. Toxic Bios: toxic autobiographies - a public environmental humanities project. Environmental Justice, Larchmont, v. 0, n. 0, p. 7-11, 2019.

ARMIERO, M.; D'ALISA, G. The garbage struggles for environmental justice in Campania, Italy. Capitalism Nature Socialism, London, v. 23, n. 4, p. 52-68, 2012.

ARMIERO, M.; DE ROSA, S. Political effluvia: smells, revelations, and the politicization of daily experience in Naples, Italy. In: THORPE, J.; RUTHERFORD, S.; ANDERS SANDBERG, L. Methodological challenges in nature-culture and environmental history research. London New York: Routledge, 2017. p. 173-186.

BARCA, S. Enclosing water: nature and political economy in a Mediterranean valley, 17961916. Cambridge: The White Horse Press, 2010.

BARCA, S. Laboring the earth: transnational reflections on the environmental history of work. Environmental History, Oxford, v. 19, n. 1, p. 3-27, 2014.

BARCA, S.; LEONARDI, E. Working-class communities and ecology: reframing environmental justice around the Ilva steel plant in Taranto (Apulia, Italy). In: SHAW, M.; MAYO, M. (Editores). Class, inequality and community development. Bristol: The policy press, 2016. p. 487-503.

BARCA, S.; LEONARDI, E. Working-class ecology and union politics: a conceptual topology. Globalizations, Abingdon-on-Thames, v. 15, n. 4, p. 487-503, 2018.

BULLARD, R. Dumping in Dixie: Race, class, and environmental quality. Boulder: Westview Press, 1990.

CAGGIANO, M.; DE ROSA, S. Social economy as antidote to criminal economy: how social cooperation is reclaiming commons in the context of Campania's environmental conflicts. Partecipazione e Conflitto, Lecce, v. 8, n. 2, p. 530-554, 2015. 
CALARESU, M. From the street to stereotype: urban space, travel and the picturesque in late eighteen-century Naples. Italian Studies, Abingdon-on-Thames, v. 62, n. 2, p. 189-203, 2007.

CAPUSSOTTI, E.; FESTA, F. L'invenzione della razza meridionale: una critica del binomio modernità-arretratezza. Alfabeta2, Milano, v. 23, out. 2012.

CARIELLO, M.; CHAMBERS, I. La questione mediterranea. Milano: Mondadori Università, 2019.

CARUSO, F. Anche i cafoni possono parlare: per una rilettura postcoloniale delle lotte della società politica meridionale. In: ORIZZONTI MERIDIANI. Briganti o emigranti: Sud e movimenti tra conricerca e studi subalterni. Verona: ombre corte, 2014. p. 161-174.

CASSANO, F. Il pensiero meridiano. Bari: Laterza, 2005.

CASSANO, F. Oltre il nulla: studio su Giacomo Leopardi. Bari: Laterza, 2011.

CAZZATO, L. Oriente within, Nord without: il meridionismo e i romantici inglesi. Altre Modernità, Milano, n. 8, p. 188-206, nov. 2012.

CHATURVEDI, V. Mapping subaltern studies and the postcolonial. London-New York: Verso Books, 2000.

CHAVARRIA, E. L'attività missionaria dei Gesuiti nel Mezzogiorno d'Italia tra XVI e XVIII secolo. In GALASSO, G.; RUSSO, C. (Editores). Per la storia sociale e religiosa del Mezzogiorno d'Italia. Napoli: Guida, 1982. v. 2, p. 159-185.

CSOA TEMPO ROSSO. L'esperienza del Movimento No-Gas e le lotte per i beni comuni in Terra di Lavoro. In: ORIZZONTI MERIDIANI. Briganti o emigranti: Sud e movimenti tra conricerca e studi subalterni. Verona: ombre corte, 2014. p. 73-81.

D'ALISA, G. et al. Conflict in Campania: waste emergency or crisis of democracy. Ecological Economics, Amsterdam, v. 70, n. 2, p. 239-249, 2010.

FERRARI BRAVO, L.; SERAFINI, A. Stato e sottosviluppo: Il caso del Mezzogiorno italiano. Milano: Feltrinelli, 1972.

FESTA, F. L'alchimia ribelle napoletana. In CAPPELLI, O. (Editor). Potere e società a Napoli a cavallo del secolo: Omaggio a Percy Allum. Napoli: Esi, 2003. p. 381-423.

FESTA, F. Questione meridionale, legislazione speciale e dibattito storiografico. “Akiris”, Napoli, v. 2, n. 4-5, p. 71-83, 2006.

FESTA, F. Orientalismo all'italiana: una genealogia del razzismo antimeridionale al tempo della crisi. Carmillaonline, 25 de junho 2013. Available at: $<$ https://www.carmillaonline. com/2013/06/25/orientalismo-allitaliana-una-genealogia-del-razzismo-antimeridionale-al-tempo-della-crisi-i-parte/> Accessed on: April 25, 2020. 
FESTA, F. Oltre l'emergenza: pratiche ed esperienza di "comune" nel Sud d'Italia. In: ORIZZONTI MERIDIANI. Briganti o emigranti: Sud e movimenti tra conricerca e studi subalterni. Verona: ombre corte, 2014. p.191-209.

GUHA, R.; SPIVAK, G. Subaltern studies: modernità e (post)colonialismo. Edição de S. Mezzadra. Verona: ombre corte, 2002.

HEGEL, G. W. Lineamenti di filosofia del diritto: Diritto naturale e scienza dello stato in compendio con le aggiunte di Eduard Gans. Edição de G. Marini. Roma-Bari: Laterza, 1987.

IACUELLI, A. Le vie infinite dei rifiuti: il sistema campano. Roma: Altrenotizie.org, 2007.

IENGO, I.; ARMIERO, M. The politicization of ill bodies in Campania, Italy. Journal of Political Ecology, v. 24, n. 1, p. 44-58, 2017.

LABORATORIO BANCAROTTA; CANTIERE SOCIALE QUARTO MONDO. Territori oltre la crisi: esperienze di riappropriazione diretta, costruzione di comunità e diritto alla città nell'area flegrea e a Napoli occidentale. In: ORIZZONTI MERIDIANI. Briganti o emigranti: Sud e movimenti tra conricerca e studi subalterni. Verona: ombre corte, 2014. p. 91-104.

LAMBROPOULOS, V. The rise of Eurocentrism: anatomy of interpretation. Princeton: Princeton University Press, 1993.

LEONARDI, E. Lecologia come frontiera mobile della condizione operaia. La società degli individui, v. 46, n. 1, p. 15-29, 2013.

LEOPARDI, G. Zibaldone. Roma: Newton Compton Editori, 2016.

LOMBARDI-DIOP, C; ROMEO, C. Postcolonial Italy: challenging national homogeneity. New York: Palgrave Macmillan, 2012.

MARMO, M. Il proletariato industriale a Napoli in età liberale. Napoli: Guida, 1978.

MARTINEZ-ALIER, J. The environmentalism of the poor: a study of ecological conflicts and valuation. Cheltenham: Edward Elgar, 2002.

MOE, N. The view from Vesuvius. Berkeley - Los Angeles - London: University of California Press, 2002.

MONTESQUIEU, C. De l'esprit des lois. Paris: Les Editions de Londres, 2015.

ORIZZONTI MERIDIANI. Briganti o emigranti: Sud e movimenti tra conricerca e studi subalterni. Verona: ombre corte, 2014.

PACE, C.; SAVOIA, N. Per chi scava la trivella: appunti sulle pratiche estrattive nel Mezzogiorno in una prospettiva postcoloniale. In: ORIZZONTI MERIDIANI. Briganti o emigranti: Sud e movimenti tra conricerca e studi subalterni. Verona: ombre corte, 2014. p. 105-115. 
PANICO, C. Lautonomia dei subalterni: La Questione meridionale da Gramsci agli studi postcoloniali. 2017. Dissertação (Mestrado em História) - Dipartimento di Civiltà e Forme del Sapere, Universidade de Pisa, Pisa, 2017.

PETRILLO, A. Biopolitica di un rifiuto: le rivolte anti-discarica a Napoli e in Campania. Verona: ombre corte, 2009.

PETRILLO, A. Il silenzio della polvere: capitale, verità e morte in una storia meridionale di amianto. Milano: Mimesis, 2015.

PETRUSEWICZ, M. Come il Meridione divenne Questione: rappresentazioni del Sud prima e dopo il Quarantotto. Soveria Manelli: Rubbettino, 1998.

PETRUSEWICZ, M. Chi ha inventato la "questione meridionale"?. In: ORIZZONTI MERIDIANI. Briganti o emigranti: Sud e movimenti tra conricerca e studi subalterni. Verona: ombre corte, 2014. p. 17-29.

PIPERNO, F. Elogio dello spirito pubblico meridionale: genius loci e individuo sociale. Roma: DeriveApprodi, 1997.

REGIONE (ITALIA). In: WIKIPÉDIA, a enciclopédia livre. Flórida: Wikimedia Foundation, 2019. Available at: <https://w.wiki/_C6s> Accessed on: December 7, 2020.

REINO DAS DUAS SICÍLIAS. In: WIKIPÉDIA, a enciclopédia livre. Flórida: Wikimedia Foundation, 2019. Available at: <https:/w.wiki/qvo> Accessed on: December 7, 2020.

SAID, E. Orientalism. London: Penguin, 1978.

SANTOS, B. Another knowledge is possible: beyond northern epistemologies. London-New York: Verso, 2007.

SCHNEIDER, J. (Editor). Italy's “Southern Question”: Orientalism in one country. London: Bloomsbury USA Academic, 1998.

SVIMEZ - ASSOCIAZIONE PER LO SVILUPPO DELLINDUSTRIA NEL MEZZOGIORNO. Sintesi rapporto SVIMEZ 2018: economia e società nel Mezzogiorno. Roma, 2018.

UNIONE DELLE PROVINCE D'ITALIA. Mappa delle province italiane. Roma, 2019. Available at <https://bit.ly/3a6K4Xu> Accessed on: April 13, 2021 


\section{Roberto Sciarelli}

$\checkmark$ r.sciarelli@gmail.com

ORCiD: https://orcid.org/0000-0003-1133-4017
Submitted on: $27 / 04 / 2020$

Accepted on: 13/05/2021 2021;24e:02462

How to cite: SCIARELLI, R. Subaltern ecologies in Southern Italy. Ambiente \& Sociedade. Ambiente $\&$ Sociedade. São Paulo, v. 24, p. 1-23, 2021. 


\title{
Ecologias subalternas no sul da Itália
}

\author{
Roberto Sciarelli
}

São Paulo. Vol. 24, 2021

Tema em destaque:

Insurgências Decolonais e Horizontes

Emancipatórios: Contribuições da Ecologia
Resumo: A Itália é um país marcado por sérias desigualdades entre suas regiões setentrionais e meridionais em termos de bem-estar, produção econômica e qualidade dos serviços públicos. $\mathrm{O}$ sul da Itália sofreu, também, graves casos de devastação ambiental. Uma corrente teórica com abordagem pós-colonial interpreta essas desigualdades como um efeito de relações de poder coloniais que fizeram do sul uma vítima histórica de representações racistas e dispositivos de governo autoritários. Outra linha de investigação se dedica ao estudo dos conflitos socioambientais surgidos no sul da Itália em situações de degradação ecológica. O objetivo deste artigo é contribuir para a aproximação entre essas duas correntes de pesquisa, evidenciando os pontos de conexão e divergência mais relevantes, com o propósito de indicar possíveis percursos de pesquisa comum para uma ecologia política pós-colonial do sul da Itália.

Palavras-chave: Sul da Itália; ecologia política; estudos pós-coloniais

Como citar: SCIARELLI, R. Ecologias subalternas no sul da Itália.. Ambiente \& Sociedade. São Paulo, v. 24, p. 1-25, 2021.

DOI: http://dx.doi.org/10.1590/1809-4422asoc20190246r2vu2021L4TD 


\title{
Ecologías subalternas en el Sur de Italia
}

\author{
Roberto Sciarelli
}

São Paulo. Vol. 24, 2021

Tema en Destaque: Insurgencias Decoloniales y Horizontes Emancipatórios: Contribuciones de la Ecología Política
Resumen: Italia es un país marcado por serias desigualdades entre sus regiones del norte y del sur, en términos de bienestar, producción económica y nivel de servicios públicos. El sur de Italia también ha sufrido graves casos de devastación ambiental. Una corriente teórica con un enfoque postcolonial interpreta estas desigualdades como un efecto de las relaciones de poder coloniales que han convertido al sur en una víctima histórica de representaciones racistas y dispositivos de gobierno autoritarios. Otra línea de investigación está dedicada al estudio de los conflictos socioambientales que han surgido en el sur de Italia en situaciones de degradación ambiental. El objetivo de este artículo es contribuir a la aproximación entre estas dos corrientes de investigación, destacando los puntos de conexión y divergencia más relevantes, con el propósito de indicar posibles caminos de investigación común para una ecología política postcolonial del sur de Italia.

Palabras-clave: Sur de Italia; ecología política; estudios postcoloniales.

Como citar: SCIARELLI, R. Ecologías subalternas en el Sur de Italia. Ambiente \& Sociedade. São Paulo, v. 24, p. 1-25, 2021.

DOI: http://dx.doi.org/10.1590/1809-4422asoc20190246r2vu2021L4TD 